\title{
First Report of Rhizoctonia solani AG-4 HG-I on Campanula trachelium in Italy
}

\author{
Angelo Garibaldi ${ }^{1} \cdot$ Domenico Bertetti $^{1} \cdot$ Slavica Matić $^{1} \cdot$ Maria Lodovica Gullino ${ }^{1}$
}

Received: 10 January 2018 / Accepted: 1 August 2018 /Published online: 6 August 2018

(C) Società Italiana di Patologia Vegetale (S.I.Pa.V.) 2018

In the autumn of 2017, a crown rot was observed on three-month-old plants of Campanula trachelium growing in a nursery located in Grugliasco (Northern Italy). Petioles rotted at the base and leaves wilted. Finally, affected plants died. Rhizoctonia solani was consistently isolated from affected tissues. Colonies did not produce sclerotia. One of these isolates was paired with $R$. solani tester strains belonging to the anastomosis groups AG-1, AG-2, AG-4, AG-7, and AG-11. The hyphal fusions were observed microscopically only with the group AG-4 (Fusion Frequency<30\%) (Sneh et al. 1991). The internal transcribed spacer (ITS) region of rDNA was amplified using the primers ITS1/ITS4 and sequenced (GenBank Accession number MG766874). BLASTn analysis (Altschul et al. 1997) of the 678 bp showed 99\% identity with the sequence AY154307 of Thanatephorus cucumeris (teleomorph of R. solani). The high identity with a member of AG-4 HG-I led the $R$. solani isolated from $C$. trachelium to this subgroup (Gónzales et al. 2016). For pathogenicity tests, three two-month-old healthy plants of $C$. trachelium were inoculated with fragments (about $5 \times 5 \times 3 \mathrm{~mm}$ ) of a single isolate of $R$. solani grown on potato dextrose agar (PDA). About seven days later, a crown rot started on inoculated plants and $R$. solani was constantly reisolated from affected petioles. $R$. solani AG-4 HG-I is reported on $C$. trachelium for the first time in Italy.

\section{References}

Altschul SF, Madden TL, Schaffer AA, Zhang Z, Miller W, Lipman DJ (1997) Gapped BLAST and PSI-BLAST: a new generation of protein database search programme. Nucleic Acids Res 25:3389-3402

Gónzales D, Rodriguez-Carres M, Boekhout T, Stalpers J, Kuramae EE, Nakatani AK, Vilgalys R, Cubeta MA (2016) Phylogenetic relationships of Rhizoctonia fungi within the Cantharellales. Fungal Biol 120:603-619

Sneh B, Burpee L, Ogoshi A (1991) Identification of Rhizoctonia species. APS Press, St. Paul
Domenico Bertetti

domenico.bertetti@unito.it

Centre of Competence for the Innovation in the Agro-Environmental Sector (AGROINNOVA), University of Turin, Via Leonardo da Vinci 44, 10095 Grugliasco, Italy 